\title{
Konsep Diversi Terhadap Anak Penyandang Disabilitas Sebagai Pelaku Tindak Pidana Dalam Sistem Peradilan Pidana Anak
}

\author{
Trisno Raharjo \& Laras A stuti
}

DATA NASKAH

Masuk: 18 September 2017

Diterima: 24 November 2017

Terbit: 1 Desember 2017

KORESPONDEN PENULIS:

Universitas Muhammadiyah Yogyakarta, Jalan Brawijaya, Tamantirto, Kasihan, Tamantirto, Kasihan, Bantul, Daerah Istimewa Yogyakarta 55184

trisnoraharjo@umy.ac.id \& larasastuti@law.umy.ac.id

\section{ABSTRAK}

Penelitian ini bertujuan untuk mengetahui konsep diversi dalam sistem peradilan pidana anak bagi anak penyandang disabilitas sebagai pelaku tindak pidana. Pola kehidupan dalam masyarakat yang dipengaruhi perkembangan teknologi informasi menjadikan kejahatan lebih mudah menjangkau anak-anak, sebagai sosok yang masih rentan untuk melakukan suatu kejahatan, termasuk bagi anak penyandang disabilitas tertentu. Anak sebagai pelaku tindak pidana akan melalui tahap dalam sistem peradilan pidana anak. Salah satu tahapan yang dapat dilalui adalah diversi. Peneliti ingin mengetahui konsep diversi terhadap anak penyandang disabilitas pelaku tindak pidana. Penelitian ini merupakan penelitian hukum normatif yang bersifat doktrinal dengan pendekatan konseptual (conceptual approach) dan pendekatan undang-undang. Penelitian hukum normatif yang berpijak pada bahan hukum sekunder sebagai bahan kajiannya untuk mencari asas-asas, doktrin-doktrin dan sumber hukum dalam arti filosofis, sosiologis dan yuridis. Dalam memperdalam kajian, penelitian ini akan menganalisis beberapa kasus di beberapa Pengadilan Negeri di D aerah Istimewa Yogyakarta. Kesimpulan penelitian ini adalah ditemukan beberapa pengaturan hukum pidana terhadap anak penyandang disabilitas. Konsep diversi terhadap anak penyandang disabilitas sebagai pelaku tindak pidana belum dapat dilaksanakan berdasarkan hasil penelusuran putusan tentang diversi dalam sistem peradilan pidana anak.

Kata Kunci: Anak, Pelaku, Disabilitas, Diversi, Sistem Peradilan Pidana Anak 


\section{ABSTRACT}

This study aims to determine the concept of diversion in the criminal justice system of children for children with disabilities as perpetrators of criminal acts. The pattern of life in a society that is influenced by the development of information technology makes it easier for crime to reach children, as a person who is still vulnerable to committing a crime, including for certain children with disabilities. C hildren as perpetrators of criminal acts will go through stages in the criminal justice system of children. Diversion is one of the hallmarks of the criminal justice system. Thus, the researcher wants to know the concept of diversion in the settlement of crime committed by the child as a person with disability. This research is a doctrinal normative legal research with conceptual approach and approach of law. N ormative legal research based on secondary legal material as a study material to look for principles, doctrines and sources of law in the philosophical, sociological and juridical sense. This study will analyze some cases in several D istrict Courts in Yogyakarta Special Region. The research result's is found some arrangement of criminal law to children with disability. The concept of diversion against children with disabilities as perpetrators of criminal offenses can not be implemented based on the results of judicial review of the verdicts on divrsion in the criminal justice system

K eywords: C hild, Perpetrators, Disability, D iversity, C hild C riminal Justice System

\section{PENDAHULUAN}

Anak dengan ketidakmampuan secara penuh yang kemudian dikenal dengan istilah penyandang disabilitas (Pasal 1 huruf 1 Undang-Undang Nomor 8 Tahun 2016 tentang Penyandang Disabilitas), masih menghadapi kendala dalam kehidupan bermasyarakat tidak terkecuali dalam sistem peradilan pidana anak. Perlindungan hukum bagi anak dapat dilakukan sebagai upaya perlindungan hukum terhadap berbagai kebebasan dan hak asasi anak. Perlindungan terhadap anak ini juga mencakup kepentingan yang berhubungan dengan kesejahteraan anak. Perlindungan anak yang berhadapan dengan hukum $(\mathrm{ABH})$, merupakan tanggung jawab bersama aparat penegak hukum. Tidak hanya anak sebagai pelaku, namun mencakup juga anak sebagai korban dan saksi (Ariani, 2014:109).

Kejahatan anak menjadi bertambah seiring dengan lajunya perkembangan industrialisasi dan urbanisasi. Di kota- kota (baik metropolitan maupun kota) dengan tingkat industri yang maju, kasus kejahatan ditemukan jauh lebih banyak daripada dalam masyarakat pedesaan. Tingkat kejahatan ini berkolerasi dengan proses industrialisasi. Tidak mengherankan semakin maju industrialisasi dan perkembangan ekonomi maka tingkat kriminalitas juga meningkat, termasuk kenakalan anak (Kartono, 2011:25).

Anak sering kali tidak mengetahui baik secara langsung maupun tidak langsung apa yang telah diperbuatnya adalah suatu tindakan yang salah sehingga menjerumus dalam tindak pidana sehingga anak dapat dikenai pasal tertentu terhadap perbuatan yang dilakukannya. Anak, berada pada usia penuh dengan keingin tahuan, belajar dengan berhadapan dengan hukum menyebabkan ruang lingkup anak menjadi terbatasi karena statusnya sebagai pelaku tindak pidana.

Anak terutama anak penyandang disabilitas terkadang banyak dimanfaatkan oleh orang-orang atau kelompok tertentu menjadi pelaku tindak pidana. Meskipun dimanfaatkan namun dihadapan hukum anak penyandang disabilitas tetap harus mempertanggungjawabkan perbuatannya. Anak penyandang disabilitas, sebagai pelaku tindak pidana memiliki sifat yang sangat rentan sebagai pelaku karena mudah dipengaruhi dan mudah juga menjadi korban karena keterbatasan mereka. Anak yang menjadi pelaku maupun menjadi korban terhadap suatu tindak pidana tentu akan memiliki dampak negatif yang akan dapat mereka rasakan secara langsung maupun akan mereka rasakan dikemudian hari. Traumatis dan stigma yang kemudian muncul merupakan salah satu efek negatif dari tindak pidana terjadi.

Penegak hukum dalam menghadapi anak disabilitas terkadang mengalami kendala baik terkait interaksi maupun fasilitas yang ada pada lembaga penegak hukum (Henry Arianto, 2016:11-12). Interaksi antara penegak hukum dengan anak penyandang disabilitas, terkendala karena tidak semua penyidik dapat memahami keperluan dan keperluan khusus anak penyandang disabilitas, disamping anak penyandang disabilitas sebagai pelaku juga kurang memahami persoalan proses penegakan hukum pidana.

Undang-Undang Nomor 11 Tahun 2012 tentang Sistem Peradilan Pidana Anak lahir sebagai upaya meminimalisir 
dampak tersebut dan sebagai upaya dalam memenuhi hakhak anak dalam menjalani proses peradilan. Istilah diversi kemudian muncul sebagai salah satu jawaban menghindari anak dari dampak negatif dari proses peradilan.

Dengan adanya pengalihan penyelesaian perkara Anak dari prosesperadilan pidana ke proses di luar peradilan pidana diharapkan mampu meminimalisir dampak negatif, menghilangkan stigma dan membuat anak sebagai pribadi yang utuh kembali dan dapat diterima secara terbuka dalam lingkungan masyarakat. Apalagi dalam Pasal 3 huruf $m$, Undang-Undang Nomor 11 Tahun 2012 tentang Sistem Peradilan Pidana Anak mengatakan bahwa setiap anak dalam proses peradilan pidana berhak mendapatkan aksesibilitas bagi penyandang cacat.

Diversi bagi anak penyandang disabilitas perlu dipahami secara baik, mengingat pelaksanaan diversi menjadikan pelaku tindak pidana bertemu dan bermusyawarah dengan korban, komunikasi menjadi kunci keberhasilan diversi, selain itu pemahaman terhadap pelaku tindak pidana yaitu anak penyandang disabilitas tidak dapat diabaikan. Tulisan ini kemudian akan mengkaji lebih lanjut, bagaimana pelaksanaan diversi terhadap anak sebagai pelaku dan penyandang disabilitas dalam sistem peradilan pidana anak.

\section{RUMUSAN MASALAH}

Berdasarkan latar belakang yang sudah diuraikan di atas, maka dapat dirumuskan masalah, bagaimana konsep pengaturan hukum pidana terhadap diversi anak penyandang disabilitas sebagai pelaku tindak pidana di Indonesia.

\section{METODE PENELITIAN}

\section{A. Jenis Penelitian}

Penelitian ini menggunakan pendekatan normatif, hukum dipandang sebagai sistem norma, berupa asas-asas, kaidah dari peraturan perundangan, putusan pengadilan, perjanjian serta doktrin (ajaran) yang berlaku disuatu negara (Fajar, Ahmad, 2010:34) dalam pelaksanaan konsep diversi terhadap anak sebagai pelaku dan penyandang disabilitas dalam sistem peradilan pidana anak.

Sebagai penelitian hukum normatif, penelitian ini hanya akan mengkaji bahan-bahan hukum, baik bahan hukum primer maupun bahan hukum sekunder. Penelitian hukum normatif yang berpijak pada bahan hukum sekunder sebagai bahan kajiannya untuk mencari asas-asas, doktrin-doktrin dan sumber hukum dalam arti filosofis, sosiologis dan yuridis. Dalam memperdalam kajian, penelitian ini akan menganalisis beberapa kasus yang diambil dari di beberapa Pengadilan Negeri di wilayah hukum Pengadilan Tinggi Yogyakarta.

\section{B. Bahan Hukum}

Bahan hukum, yang digunakan berasal dari studi kepustakaan yang terdiri atas:

1. Bahan hukum primer, yaitu berupa peraturan perundangundangan terkait dengan proses pengadilan anak yang terdapat dalam, Kitab Undang-undang Hukum Pidana, Kitab Undang-undang Nomor 8 Tahun 1981 tentang Hukum Acara Pidana, Undang-Undang Nomor 19 Tahun 2011 tentang Convention On The Rights Of Persons With Disabilities (Konvensi mengenai Hak-Hak Penyandang Disabilitas), Undang-undang Nomor 11 Tahun 2012 tentang Sistem Peradilan Pidana Anak, Undang-Undang Nomor 8 Tahun 2016 tentang Penyandang Disabilitas, Peraturan Daerah Istimewa Yogyakarta Nomor 4 Tahun 2012 tentang Perlindungan dan Pemenuhan Hak-Hak Penyandang Disabilitas. Adapun putusan pengadilan yang menjadi dasar penelitian antara lain: Putuan Pengadilan Negeri Wonosari Nomor: 06/Pen.Pid.Sus.Anak/2016/Pn.Wno, Putusan Pengadilan Negeri Yogyakarta Nomor: 02/Pid-Sus-Anak/ 2016/Pn.YYK, dan Putusan Pengadilan Negeri Sleman Nomor: 25/Pid.Sus-Anak/2017/Pn.Slmn

2. Bahan hukum sekunder, yaitu berupa literatur, data elektronik dan data lain yang berhubungan dengan konsep diversi terhadap anak penyandang disabilitas sebagai pelaku tindak pidana dalam sistem peradilan pidana anak.

3. Bahan hukum tersier, yaitu berupa kamus bahasa inggris, kamus bahasa indonesia, kamus istilah hukum, Black's Law Dictionary.

\section{Metode Analisis}

Metode penelitian yang dipergunakan adalah deskriptif kualitatif, artinya data yang diperoleh akan digambarkan 
sedemikian rupa dengan tolak ukur peraturan perundangundangan yang berlaku dan berhubungan dengan judul serta membandingkan dengan teori yang berlaku dan fakta yang diperoleh.

\section{HASIL PENELITIAN DAN ANALISIS}

\section{A. Pengaturan Hukum terhadap Anak Penyandang D isabilitas}

1. Undang-Undang Nomor 19 Tahun 2011 tentang Convention On The Rights Of Persons With Disabilities (Konvensi mengenai Hak-Hak Penyandang Disabilitas)

Ratifikasi yang dilakukan oleh Indonesia pada tanggal 10 November 2011 Konvensi mengenai Hak-Hak Penyandang Disabilitas melalui Undang-Undang Nomor 19 Tahun 2011 menunjukkan bahwa Pemerintah Indonesia berkomitmen dan bersungguh-sungguh dalam menghormati, melindungi dan memenuhi hak penyandang disabilitas. Sehingga penyandang disabilitas bebas dari penyiksaan, perlakuaan yang semena-mena, tidak manusiawi, diskriminatif, eksploitasi, serta berhak atas perlindungan hukum apabila penyandang disabilitas berhadapan dengan hukum. Ketentuan dalam Konvensi mengenai Hak-Hak Penyandang Disabilitas dalam bidang hukum, tertuang dalam Pasal 13 yang mengatur tentang akses terhadap keadilan. Ketentuan ini mengharuskan Indonesia melakukan pengaturan yang memberikan akses yang baik bagi penyandang disabilitas saat berhadapan dengan hukum, serta meningkatkan kompetensi terhadap penegak hukum dan petugas lembaga pemasyarakatan. Pasal 15 Konvensi mengatur penyandang disabilitas harus dapat dicegah dari perlakukan penyiksaan dan pengenaan hukuman yang kejam tidak manusiawi dan merendahkan martabat manusia. Maka pengaturan terhadap model penegakan hukum dan penghukuman terhadap anak penyendang disabilitas seperti dalam pendekatan keadilan restoratif menjadi relevan dilakukan dalam perundang-undangan di Indonesia.

2. Undang-Undang Nomor 8 Tahun 2016 tentang Penyandang Disabilitas

Undang-Undang Nomor 8 Tahun 2016 tentang Penyandang Disabilitasmerupakan undang-undang tentang penyandang disabilitas yang mengedepankan hak asasi manusia yang tidak diketemukan dalam Undang-Undang Nomor 4 Tahun 1997 tentang Penyandang Disabilitas sebelumnya. Undang-undang sebelumnya lebih banyak bernuansa diskriminatif sehingga hak penyandang disabilitas belum sepenuhnya terlaksana. Undang-undang ini memuat terutama pengaturan tentang hak dan perlindungan yang didapatkan anak apabila berhadapan dengan hukum.

Amanat Pasal 37 Undang-Undang Nomor 8 Tahun 2016 tentang Penyandang Disabilitas, Rumah Tahanan Negara dan Lembaga Pemasyarakatan wajib menyediakan Unit Layanan Disabilitas. Unit layanan disabilitas sebagaimana dimaksud pada ayat (1) berfungsi, memastikan apabila terdapat anak penyandang disabilitas, maka dalam kurun waktu tidak kurang dari enam bulan pelayanan di tempat penahanan atau lembaga pemasyarakatan dapat dilaksanakan baik berupa sarana dan prasarana maupun obat-obatan yang melekat pada anak penyandang disabilitas. Termasuk penyediaan bagi kebutuhan khusus adalah memberikan layanan rehabilitasi untuk penyandang disabilitas mental.

3. Undang-Undang Nomor 11 Tahun 2012 tentang Sistem Peradilan Pidana Anak

Ciri dan sifat yang khas pada anak memberikan konsekuensi bahwa demi perlindungan terhadap anak, maka perkara anak haruslah disidangkan di peradilan pidana anak. Sama dengan proses peradilan pada peradilan umum lainnya, maka anak harus melewati setiap tahapan dimulai dari penangkapan, penahanan, dan proses peradilan. Penegak hukum dalam sistem peradilan pidana anak wajib memiliki kompetensi dalam menangani tindak pidana yang melibatkan anak. Disamping pemahaman yang baik terhadap penegakan hukum terhadap anak yang berhadapan dengan hukum, juga diperlukan kompetensi yang baik saat menghadapi anak yang berkebutuhan khusus sebagai penyandang disabilitas. Tidak terkecuali pada pelaksanaan diversi berdasarkan pendekatan keadilan restoratif yang merupakan proses penyelesaian di luar jalur pengadilan, diperlukan tenaga pendamping yang memiliki pemahaman yang baik terhadap kebutuhan khusus anak penyandang disablitas.

4. Peraturan Daerah Provinsi Daerah Istimewa Yogyakarta Nomor 4 Tahun 2012 tentang Perlindungan dan Pemenuhan Hak-Hak Penyandang Disabilitas 
Fakta yang banyak terjadi dalam kehidupan bermasyarakat dan bernegara terutama di Daerah Istimewa Yogyakarta pasca bencana gempa bumi pada bulan Mei 2006 jumlah populasi penyandang disabilitas meningkat. Kondisi yang demikian membuat kehidupan penyandang disabilitas memprihatinkan. Ditambah lagi dengan berbagai bentuk diskriminasi sehingga banyak hak-hak yang belum terpenuhi. Padahal penyandang disabilitas sebagaimana warga negara lainnya juga berhak mendapatkan hak, kewajiban dan kedudukan yang sama sebagaimana yang telah diamanatkan dalam UUD 1945. Peraturan Daerah Nomor 4 Tahun 2012 perlu untuk dilakukan pembaharuan mengingat telah keluarnya Undang-Undang Nomor 8 Tahun 2016.

\section{B. Pelaksanaan konsep Diversi terhadap Anak Penyandang D isabilitas sebagai Pelaku Tindak Pidana dalam peraturan perundang- undangan}

Tidak dapat dipungkiri bahwa selama ini masyarakat mengenal istilah disabilitas sebagai seseorang penyandang cacat. Cacat atau kecacatan sering kali diartikan sebagai individu atau seseorang yang kehilangan anggota atau struktur tubuh seperti kehilangan anggota tangan atau kaki, mengalami kebutaan atau tuli pada pendengaran sampai dengan kelumpuhan pada seluruh anggota tubuh. Kecacatan juga di artikan memiliki hambatan dalam perkembangan pola pikir seperti idiot. Pembatasan makna disabilitas dengan kecacatan inilah yang menyebabkan undercoverage, sehingga pendataan disabilitas yang mengacu pada konsep kecacatan akan menghasilkan data yang underestimate (bps.go.id diakses pada 10 Agustus 2017).

Pengertian disabilitas selanjutnya dirumuskan ulang sebagai orang yang memiliki keterbatasan fisik, mental, intelektual, atau sensorik dalam jangka waktu lama yang dalam berinteraksi dengan lingkungan dapat menemui hambatan yang menyulitkan untuk berpartisipasi penuh dan efektif. Penekanan makna disabilitas dalam konsep ini adalah adanya gangguan fungsi yang berlangsung lama dan menyebabkan terbatasnya partisipasi di masyarakat (bps.go.id diakses pada 10 Agustus 2017).

Perumusan tersebut disepakati sebagaimana yang tertuang dalam Convention on the Right of Person with Disabilities (CRPD) tahun 2007 di New York, Amerika Serikat. Indonesia meratifikasinya dalam Undang-Undang Nomor 19 Tahun 2011 tentang Pengesahan Konvensi mengenai HakHak Penyandang Disabilitas pada tanggal 18 Oktober 2011.

Penyandang disabilitas tidak hanya dapat dialami secara alami berdasarkan genetis atau kelainan genetis tetapi juga dapat dialami oleh seseorang yang semula dalam keadaan sehat dan normal kemudian karena sakit atau kecelakaan kerja, lalu lintas atau dalam keadaan perang memiliki kondisi yang dapat dikategorikan sebagai penyandang disabilitas.

Penyandang disabilitas juga tidak hanya terbatas pada orang dewasa namun anak-anak juga banyak menyandang disabilitas. Selama ini kita mengetahui dan cenderung memberikan stigma bagi penyandang disabilitas bahwa mereka adalah sosok yang lemah, tidak berdaya sehingga tidak mungkin melakukan hal-hal yang berhubungan dengan kriminalitas atau melakukan tindak pidana tertentu.

Mahogany Wright (Eddyono \& Kamilah, 2015:9) memberikan tanggapan umum dari orang-orang dengan penyandang disabilitas intelektual yang dapat mempengaruhi kemampuan mereka untuk melindungi hak-hak mereka sebagai berikut. Sebagai tersangka, individu penyandang disabilitas seringkali dilabeli bahwa:

1. Penyandang disabilitas tidak ingin ketidakmampuan mereka untuk diakui dan orang ukan penyandang disabilitas pikir para penyandang disabilitas tersebut mencoba untuk menutupi kedisabilitasannya;

2. Penyandang disabilitastidak memahami hak-hak mereka, namun seolah-olah mereka paham;

3. Penyandang disabilitas tidak mengerti perintah, instruksi dan lain-lain;

4. Penyandang disabilitas selalu merasa terganggu oleh kehadiran polisi;

5. Penyandang disabilitas selalu bertindak marah pada saat ditahan dan/atau mencoba melarikan diri;

6. Penyandang disabilitas mengatakan apa yang mereka pikirkan dan ingin para petugas tersebut dapat memahami pikiran mereka;

7. Penyandang disabilitas mengalami kesulitan menjelaskan fakta atau rincian pelanggaran;

8. Penyandang disabilitas menjadi orang yang pertama 


\section{MEDIA \\ HUKUM}

meninggalkan TKP, namun selalu yang pertama kali tertangkap;

9. Penyandang disabilitas memiliki kebingungan tentang siapa yang harus bertanggungjawab atas kejahatan atau justru dirinya harus "mengaku" bersalah saja atas apa yang tidak ia lakukan.

Individu penyandang disabilitas dengan status tersangka, meskipun memiliki jumlah yang sedikit, namun presentasenya menunjukkan peningkatan. Pelaku tindak pidana yang memiliki disabilitas intelektual misalnya terdiri dari 2\%-3\% dari populasi umum, mereka juga mewakili $4 \%$ sampai $10 \%$ dari populasi penjara. Studi di penjara negara bagian dan federal Amerika menemukan bahwa kurang dari $1 \%$ narapidana memiliki cacat fisik/disabilitas fisik, sementara $4.2 \%$ memiliki keterbelakangan mental disabilitas intelektual (Eddyono \& Kamilah, 2015:10).

Kelemahan dan ketidak berdayaan tersebut justru acap kali dimanfaatkan oleh beberapa oknum atau pihak-pihak yang berusaha mendapatkan keuntungan dari ketidakberdayaan penyandang disabilitas. Penyandang disabilitas dengan ketidaktahuan mereka atau keterpaksaan mereka melakukan hal-hal yang dilarang sehingga mengarahkan mereka pada kriminalitas. Mereka dimanfaatkan untuk melakukan tindak pidana tertentu sehingga untuk mempertanggungjawabkan perbuatannya mereka tetap harus mengikuti setiap prosedur dalam sistem peradilan pidana sampai hakim memberikan putusan yang menetapkan bersalah atau tidaknya mereka atas perbuatan yang dilakukan.

Permasalahan yang muncul kemudian adalah ketika anakanak penyandang disabilitas yang menjadi pelaku dalam tindak pidana tersebut dan mempertanggungjawabkan perbuatan mereka. Dalam hukum pidana Indonesia, anakanak yang berhadapan dengan hukum maka tetap akan diproses sebagaimana ketentuan yang berlaku dalam sistem peradilan pidana anak di Indonesia. Komponen yang bekerja dalam sistem peradilan pidana adalah kepolisian, kejaksaan, pengadilan dan lembaga pemasyarakatan, (Reksodiputro, 1994:140-141) termasuk di dalamnya sistem peradilan pidana anak. Perbedaan sistem peradilan pidana anak dengan sistem peradilan pidana adalah bentuk formal atribut dan lingkup penggunaan upaya paksa yang dibatasi.

Sistem peradilan pidana anak di Indonesia mendasarkan pada keadilan restoratif yang menekankan kepada pemulihan kembali pada keadaan semula dan bukan pada pembalasan. Sebagai konsekuensi dari penerapan keadilan restoratif dalam sistem peradilan pidana anak dikembangkan sistem diversi untuk dapat melakukan penyelesaian perkara anak di luar proses dan tahapan peradilan pidana.

Ide dasar diversi pertama kali dicanangkan dalam United Nations Standard M inimum Rules for the Administration of Juvenile Juatice (SM RJJ) atau dikenal dengan The Beijing Rules. Melalui diversi aparat penegak hukum diberikan kewenangan untuk menangani atau menyelesaikan perkara pidana yang melibatkan anak dengan tidak mengambil jalan formal dengan melakukan pengalihan proses peradilan pidana dengan mempertemukan dengan korban tindak pidana dan memungkinkan pengembalian atau penyerahan anak kepada masyarakat dalam bentuk-bentuk kegiatan pelayanan sosial (Pramukti \& Primaharsya, 2015:67-68).

Diversi harus mulai dilaksanakan sejak di tingkat penyidikan, penuntutan dan pemeriksaan perkara anak di pengadilan negeri. Memang tidak semua tindak pidana dapat diupayakan diversi, hanya tindak pidana dengan ancaman pidana penjara di bawah 7 (tujuh) tahun dan bukan merupakan pengulangan tindak pidana saja yang dapat di upayakan diversi.

Pelaksanaan diversi di Indonesia sebagaimana yang diamanatkan dalam Undang-Undang Nomor 11 Tahun 2012 tentang Sistem Peradilan Pidana Anak baru dilaksanakan sejak Juli 2014. Pelaksanaan peradilan pidana anak di Indonesia memang relatif masih baru, sehingga masih ditemukan celah kelemahan atau evaluasi terhadap sistem yang bekerja. Belum siapnya sarana dan prasarana di setiap tingkatan proses penegakan hukum serta kurangnya pemahaman penegak hukum terhadap kebutuhan khusus anak penyandang disabilitas.

Diversi sendiri berdasarkan Pasal 6 Undang-Undang Nomor 11 Tahun 2012 tentang Sistem Peradilan Pidana Anak bertujuan, mencapai perdamaian antara korban dan anak, melalui penyelesaian perkara di luar proses peradilan guna menghindari anak dari perampasan kemerdekaan. Proses diversi melibatkan tidak saja korban dan anak pelaku tindak pidana namun juga masyarakat yang terdampak akibat perbuatan pidana anak tersebut. 
Sistem peradilan pidana anak mewajibkan diversi dilakukan sejak tingkat penyidikan, penuntutan, dan pemeriksaan perkara anak di pengadilan negeri. Perlu diketahui bahwa untuk dapat dilakukannya diversi selain adanya persetujuan dari korban dan keluarga penegak hukum harus memperhatikan beberapa kategori tertentu sebagaimana yang tertuang dalam Pasal 7 ayat (2) Undangundang sistem peradilan pidana, yang menegaskan tindak pidana tersebut diancam dengan pidana penjara di bawah 7 (tujuh) tahun dan bukan merupakan pengulangan tindak pidana.

Anak penyandang disabilitas sebagai pelaku tindak pidana dalam menjalankan hukumannya berada di lembaga pemasyarakatan atau yang di kenal dengan Lembaga Pembinaan Khusus Anak (LPKA). Hanya saja tahanan anak penyandang disabilitas ini termasuk dalam kelompok rentan. M ereka banyak mengalami tekanan hebat akibat kondisi penjara yang buruk. Dengan kondisi yang demikian mereka juga tidak diberikan konseling atau perawatan khusus dalam memaklumi keadaan mereka yang disabilitas. Malah, banyak diantara dari mereka yang menjadi korban, dianiaya, disiksa. Fasilitas dalam tahanan juga tidak dapat mendukung aktivitas mereka sebagai penyandang disabilitas (Colbran, 2010:10).

Dalam kasus pidana, sejak mulai dari penangkapan penyandang disabilitas tampaknya telah menghadapi sistem yang tidak dirancang untuk menangani sejumlah besar penyandang cacat. Kurangnya akses keperawatan kesehatan mental masyarakat dan pelayanan publik lainnya. M ereka yang terbukti bersalah dan terbatas dalam fasilitas pidana cenderung untuk dipaksa memahami kalimat lama seperti sebelumnya yakni "dihukum karena kejahatan yang sama" dan kondisi lembaga pemasyarakatan tetap merespon keras meskipun mereka menyandang gelar disabilitas.

Hak-hak penyandang disabilitas dalam proses penegakan hukum menurut M Syafi'ie belum sepenuhnya dijamin oleh penegakan hukum yang berakibat proses hukum belum mampu mewujudkan hak atas peradilan yang adil. Hak para penyandang disabilitas yang belum terpenuhi tersebut meliputi belum diberikan sepenuhnya pendamping bagi anak (Syafi'ie, 2014:37). A pabila anak tidak dapat berbahasa Indonesia pemeriksaan tidak dilakukan dengan hadirnya penerjemah. Dibeberapa daerah belum sepenuhnya pemeriksaan dilakukan oleh penyidik, jaksa penuntut umum dan hakim yang memahami masalah anak, khususnya anak penyandang disabilitas. Anak sebagai pelaku terkadang tidak diberitahu perkembangan kasus yang sedang ditangani penyidik, jaksa, maupun hakim.

Keterbatasan anak penyandang disabilitas, menjadikan aparat penegak hukum untuk memiliki kemampuan dan pemahaman terhadap kebutuhan khusus para penyandang disabilitas tersebut. Kondisi ini tidak terlepas dengan kemampuan dan kecakapan yang tidak sama dari penyandang disabilitas. Seringkali mereka tidak dapat memenuhi kebutuhan hidupnya sendiri tanpa bantuan dari orang lain. Akibatnya, ketika disabel menjadi korban atau pelaku tindak pidana, seringkali mereka tidak menyadari bahwa mereka memiliki hak berkebutuhan khusus yang dapat dipenuhi terutama ketika berhadapan dengan sistem peradilan pidana.

\section{Konsep Penerapan diversi terhadap pelaku anak penyandang disabilitas di Pengadilan Negeri pada wilayah hukum Pengadilan Tinggi Yogyakarta.}

Diversi sebagai bentuk kebijakan hukum pidana yang dikembangkan dalam sistem peradilan pidana anak diharapkan dapat memenuhi hak anak terhadap keadilan saat anak berhadapan dengan hukum, terutama bagai anak penyandang disabilitas. Diversi disinyalir dapat membawa angin segar dalam penyelesaian tindak pidana yang dilakukan oleh anak sehingga penyelesaian dapat dilakukan dengan adil dan tidak mengganggu psikologis anak secara berkepanjangan. Secara singkat diversi dapat diartikan sebagai suatu pengalihan perkara agar tidak masuk dalam ranah peradilan pidana.

Kasus anak penyandang disabilitas yang berhadapan dengan hukum sebagai pelaku memang mungkin terjadi. Di tengah ketidakberdayaan mereka untuk melawan atau didorong faktor ketidaktahuan dan keterpaksaan maka mereka menjadi rentan untuk menjadi pelaku tindak pidana tertentu. A pabila mereka melakukan tindak pidana maka sudah sepantasnya mereka mempertanggungjawabkan perbuatan mereka dengan batas-batas tertentu yang sudah 
ditentukan sesuai dengan hukum pidana dan undangundang yang berlaku.

Sistem peradilan pidana anak menurut Wahyudi (2010:35) terdiri dari institusi atau lembaga penegak hukum yang terdiri dari polisi, jaksa, penuntut umum, dan penasehat hukum, lembaga pengawasan, pusat-pusat penahanan anak dan fasilitas pembinaan anak. Masingmasing institusi atau lembaga penegak hukum memiliki tugas berbeda-beda namun semuanya diberikan ruang untuk melakukan diversi, yang bertujuan untuk menjamin keadilan demi kesejahteraan anak dan kepentingan anak.

Sistem peradilan pidana anak dalam melaksanakan diversi terhadap anak yang berhadap dengan hukum adalah penyidik wajib mengupayakan diversi dalam waktu paling lama 7 (tujuh) hari setelah penyidikan di mulai dan paling lama 30 (tiga puluh) hari. Apabila diversi berhasil maka penyidik membuat berita acara diversi beserta kesepakatan diversi kepada ketua Pengadilan Negeri untuk dibuat penetapan. Bila diversi tidak berhasil penyidik wajib melanjutkan penyidikan dan melimpahkan perkara ke Penuntut Umum dengan melampirkan berita acara diversi dan laporan penelitian masyarakat.

Penuntut umum setelah mendapatkan pelimpahan dari penyidik, setelah memepelajari berkas perkara wajib mengupayakan Diversi, dengan ketentuan waktu yang sama dengan waktu diversi pada saat penyidikan. Diversi tetap diupayakan meskipun pada tahap penyidikan telah dilakukan upaya diversi namun gagal. Apabila diversi berhasil maka Penuntut Umum menyampaikan berita acara diversi beserta kesepakatan diversi kepada ketua Pengadilan Negeri untuk dibuat penetapan. Bila diversi tidak berhadil maka Penuntut Umum wajib menyampaikan berita acara diversi dan melimpahkan perkara ke Pengadilan dengan melampirkan laporan hasil penelitian kemasyarakatan.

Hakim saat memeriksa perkara pidana anak dapat mengupayakan diversi, terutama apabila setelah mempelajari berkas dan laporan penelitian kemasyarakatan hakim merasa perlu melaksanakan diversi. Waktu pelaksanaan diversi tidak berbeda dengan waktu yang ditetapkan undang-undang pada tahap penyidikan maupun penuntutan. A pabila diversi berhasil maka Hakim menyampaikan berita acara diversi beserta kesepakatan diversi kepada ketua Pengadilan Negeri untuk dibuat penetapan. Bila diversi gagal maka perkara dilanjutkan ke tahap persidangan.

Apabila anak dilakukan penahanan rumah maka petugas kemasyarakatan bertugas membuat laporan penelitian

Tabel 1. Pelaksanaan D iversi

\begin{tabular}{|c|c|c|c|}
\hline NO. & WILAYAH HUKUM & $\begin{array}{l}\text { RINCIAN KASUS } \\
\text { (PELAKU DAN KASUS) }\end{array}$ & $\begin{array}{l}\text { TAHAPAN } \\
\text { (PENYIDIKAN, PENUNTUTAN, PENGADILAN) }\end{array}$ \\
\hline 1. & $\begin{array}{l}\text { Pengadilan Negeri } \\
\text { Wonosari }\end{array}$ & $\begin{array}{ll}\text { a. } & \text { Pelaku : } \\
& \text { Nugroho Amin Saputro (15 Tahun) } \\
\text { b. } & \text { Kasus : } \\
& \text { Perkara kecelakaan Ialu lintas }\end{array}$ & $\begin{array}{l}\text { Diversi berhasil pada tahapan penyidikan } \\
\text { Nomor : 6/Pen.Pid.Sus.Anak/2016/PN.Wno }\end{array}$ \\
\hline 2. & $\begin{array}{l}\text { Pengadilan Negeri } \\
\text { Yogyakarta }\end{array}$ & $\begin{array}{l}\text { a. Pelaku : } \\
\text { Angky Wicaksana Setiatama } \\
\text { Arif Ginanjar } \\
\text { b. Kasus } \\
\text { Penganiayaan terhadap Arif Wahyu Ramadhan, } \\
\text { yang mana perbuatan tersebut diatur dan } \\
\text { diancam pidana dalam Pasal } 170 \text { ayat (2) ke- } \\
1 \text { KUHP, atau diatur dan diancam pidana } \\
\text { dalam pasal } 351 \text { ayat (1) KUHP J o Pasal } 55 \\
\text { Ayat (1) Ke-1 KUHP }\end{array}$ & $\begin{array}{l}\text { Diversi berhasil pada tahapan Proses Penuntutan, } \\
\text { sehingga memerintahkan penuntut umum untuk } \\
\text { menerbitkan surat perintah penghentian } \\
\text { penuntutan/hakim unutk mengeluarkan penetapan } \\
\text { penghentian pemeriksaan setelah kesepakatan } \\
\text { diversi dilaksanakan sepenuhnya/seluruhnya } \\
\text { Nomor perkara : 02/Pid-Sus-Anak/2016/PN.YYK }\end{array}$ \\
\hline 3. & $\begin{array}{l}\text { Pengadilan Negeri } \\
\text { Sleman }\end{array}$ & $\begin{array}{ll}\text { a. } & \text { Pelaku: } \\
& \text { Rafi Nurrijal Rusmanudin (16 Tahun) } \\
\text { b. } & \text { Kasus : } \\
& \text { Melakukan tindak pidana tanpa hak menguasai } \\
& \text { dan membawa senjata sebagaimana diatur dan } \\
& \text { diancam pidana dalam Pasal } 2 \text { ayat (1) } \\
& \text { Undang-Undang Darurat Nomor. } 12 \text { Tahun } \\
& \text { 1951, dihukum dengan hukuman penjara } \\
& \text { setinggi-tingginya sepuluh tahun }\end{array}$ & $\begin{array}{l}\text { Diversi tidak berhasil sehingga sampai tahapan } \\
\text { Peradilan yang memberikan hukuman terhadap } \\
\text { terdakwa. } \\
\text { Putusan pengadilan Negeri Sleman Nomor. } \\
\text { 25/Pid.Sus-Anak/2017/Pn.SImn }\end{array}$ \\
\hline
\end{tabular}

Sumber: D iolah dari Putusan Pengadilan 
Tabel 2. Layanan Aksesibilitas

\begin{tabular}{lll}
\hline NO. & AKSESIBILITAS FISIK & AKSESIBILITAS PROSEDURAL \\
\hline 1. & Gedung Peradilan : & Ketentuan mengenai saksi : \\
& $\begin{array}{l}\text { Gedung peradilan bertingkat dengan lantai yang berundak } \\
\text { pasti akan menyulitkan bagi penyandang disabilitas fisik } \\
\text { (pengguna kursi roda atau kruk/tongkat jalan penyangga } \\
\text { kaki) untuk mengakses keadilan }\end{array}$ & $\begin{array}{l}\text { Bahwa saksi sebagaimana yang terdapat dalam kitab hukum acara } \\
\text { pidana adalah mereka yang melihat, mendengar dan mengalami } \\
\text { tindak pidana tertentu. Hal ini tentu memiliki lingkup yang sangat } \\
\text { sempit, karena ketentuan tersebut mengganggu akses penyandang } \\
\text { disabilitas dalam memberikan kesaksian terutama mereka yang } \\
\text { tunanetra maupun tunarungu. }\end{array}$ \\
\hline 2. & $\begin{array}{l}\text { Berkas-berkas dalam setiap tahapan peradilan yang dibuat } \\
\text { dalam bentuk hard copy pasti akan menyulitkan bagi } \\
\text { penyandang tunanetra }\end{array}$ & $\begin{array}{l}\text { Alat bukti haruslah mulai diperluas, bagi penyandang disabilitas dapat } \\
\text { mulai dipertimbangkan alat bukti yang melalui indera penciuman }\end{array}$ \\
& $\begin{array}{l}\text { korban, keterangan korban, melalui indera pendengaran korban, dan } \\
\text { melalui indera perabaan korban. }\end{array}$ \\
\hline 3. & $\begin{array}{l}\text { Proses peradilan dalam bentuk tanya jawab yang } \\
\text { menggunakan bahasa baku dan rumit pasti akan menyulitkan } \\
\text { bagi penyandang disabilitas intelektual maupun tuna rungu } \\
\text { untuk memahami proses tersebut. }\end{array}$ \\
\hline
\end{tabular}

Sumber: M arzuki, 2015:16

kemasyarakatan untuk kepentingan diversi, melakukan pendampingan, pembimbingan, dan pengawasan terhadap anak selama proses diversi dan pelaksanaan kesepakatan, termasuk melaporkannya kepada pengadilan apabila diversi tidak dilaksanakan. Apabila diversi tidak berhasil dan anak dijatuhkan pidana oleh hakim, maka petugas lembaga pemasyarakatan melakukan pendampingan, pembimbingan, dan pengawasan terhadap anak yang memperoleh asimilasi, pembebasan bersyarat cuti menjelang bebas dan cuti bersyarat.

Pada tahapan pemidanaan disamping terdapat petugas kemasyarakatan juga terdapat Pekerja Sosial Profesional dan Tenaga Kesejahteraan Sosial yang bertugas melakukan pembimbingan, membantu, melindungi, dan mendampingi anak agar anak memiliki kembali kepercayaan diri. Pekerja sosial guna mengembalikan kepercayaan diri anak haru mampu menjadi sahabat anak dengan mendengarkan pendapat anak dan menciptakan suasana kondusif, sehingga anak memahami kekeliruan perbuatan dan mampu merubah perilaku. M elakukan advokasi sosial sehingga masyarakat tidak memberikan stikma negatif terhadap anak yang telah dikenakan pemidanaan.

Petugas sosial setelah melaksanakan tugas pendampingan terhadap anak memberikan laporan dan pertimbangan kepada aparat penegak hukum untuk penanganan rehabilitasi sosial anak. Sehingga pada akhimya anak dapat menyelesaikan hukumannya dan dapat kembali kepada orang tua dan diterima oleh lingkungan sosialnya dalam masyarakat.
Pelaksanaan diversi secara keseluruhan sudah dilaksanakan di Pengadilan Negeri yang berada di wilayah hukum Pengadilan Tinggi Yogyakarta. Hanya saja yang secara spesifik pelaku anak penyandang disabilitas memang tidak ditemukan dalam putusan pengadilan pada kasus anak. Sebagaimana amanat undang-undang peradilan anak, maka diversi sudah mulai dilaksanakan sejak tahap pertama yaitu penyidikan sampai tahap terakhir yaitu proses pemeriksaan di pengadilan. Dan untuk dapat dilakukan diversi maka harus memenuhi persyaratan pelaksanaan diversi tersebut, karena tidak semua perkara dapat dilakukan diversi.

Beberapa kasus yang dapat dianalisis oleh peneliti terkait pelaksanaan diversi di wilayah Pengadilan Negeri di Daerah Istimewa Yogyakarta bisa dilihat pada Tabel 1 .

Berdasarkan tabel diatas maka dapat disimpulkan bahwa dari 3 tahapan tersebut, hanya 2 tahapan saja yang berhasil melaksanakan diversi yakni di tahapan penyidikan (Pengadilan Negeri Wonosari) dan penuntutan (Pengadilan Negeri Yogyakarta). Berhasilnya diversi tersebut maka memberikan konsekuensi bagi Ketua Pengadilan Negeri setempat untuk membuat Penetapan Diversi yang berarti bahwa perkara tersebut berhasil diselesaikan menggunakan diversi sebagaimana kesepakatan para pihak. Sedangkan diversi tidak berhasil dilakukan ketika Hakim menjatuhkan hukuman pidana tertentu pada proses peradilan dan mewajibkan terdakwa anak untuk melaksanakan hukuman tersebut seperti yang terjadi di Pengadilan Negeri Sleman.

Terkait dengan akses peradilan terhadap pelaksanaan diversi terhadap anak penyandang disabilitassebagai pelaku, 
maka sebagaimana kasus anak lainnya anak penyandang disabilitas sebagai pelaku juga haruslah dilakukan upaya diversi. Adapun tahapan proses diversi pun tidakjauh berbeda dengan yang di lewati oleh anak-anak yang berhadapan dengan hukum lainnya. Hanya saja perlu diperhatikan beberapa hal terkait hak-hak yang bagi anak penyandang disabilitas sebagai pelaku apabila mereka melewati tahapan tersebut.

Akses penegakan hukum haruslah memberikan anak penyandang disabilitas sebagai pelaku atas peradilan yang adil, dimulai dengan memperkuat peran sistem peradilan pidana anak. Pasal 14 ketentuan International Covenant on Civil and Political Rights memberikan jaminan prosedural (procedural guarantee) agar peradilan dapat berjalan dengan baik dan adil. Peradilan haruslah secara khusus memperhatikan kebutuhan bagi anak penyandang disabilitas sebagai pelaku yang tentunya berbeda dengan anak-anak lainnya. Kebutuhan tersebut dapat dilihat dari ketersediaan layanan yang berkaitan dengan aksesibilitas fisik dan aksesibilitas prosedural (M arzuki, 2015:15).

Aksesibilitas fisik terkait dengan fasilitas yang ada dalam peradilan. Fasilitas tersebut haruslah dapat menunjang aksesibilitas bagi anak penyandang disabilitas sebagai pelaku. Gedung pengadilan beserta dengan isinya haruslah disesuaikan dan tidak menyulitkan bagi pengguna anak penyandang disabilitas sebagai pelaku. Aksesibilitas prosedural sendiri berkaitan dengan ketentuan dalam hukum acara pidana sehingga ketentuan tersebut haruslah disesuaikan dengan penyandang disabilitas sebagai pelaku. Di wilayah hukum Pengadilan Tinggi Yogyakarta secara umum hanya Pengadilan Negeri Wonosari yang telah mengupayakan pemenuhan bagai penyandang disabilitas yang berhadapan dengan hukum.

Berikut adalah contoh ketersediaan layanan yang berkaitan dengan aksesibilitasfisik dan aksesibilitas prosedural (Lihat Tabel 2). Berdasarkan tabel tersebut, seharusnya ada perubahan terkait ketentuan bagi penyandang disabilitas terutama yang dilakukan oleh anak agar anak tetap dapat mengakses keadilan sebagaimana mestinya dan diperlakukan sama dengan melihat kebutuhan mereka tanpa melakukan diskriminasi atau malah menghilangkan hak-hak mereka sebagai warga negara yang dijamin hak asasi manusia oleh undang-undang. Perubahan tersebut haruslah dimulai pada setiap tahapan proses peradilan, baik tingkat penyidikan, penuntutan, proses pemeriksaan peradilan, sampai lembaga pemasyarakatan. Tidak hanya perubahan terhadap proses bagi penyandang disabilitas saja, melainkan bagi para aparat penegak hukum juga. Para penegak hukum haruslah dibekali dengan kompetensi apabila menghadapi kasus yang melibatkan penyandang disabilitas. Proses perubahan tersebut haruslah mulai memperhatikan ketersediaan penerjemah, akses terhadap penggunaan huruf braile yang mulai disiapkan sejak tahap penyidikan. Selain itu ketentuan terhadap rumah tahanan juga sudah mulai memperhatikan akomodasi bagi penyandang disabilitas dengan menyediakan Unit Layanan Disabilitas sebagaimana ketentuan dalam undang-undang.

\section{KESIMPULAN DAN SARAN}

\section{A. KESIMPU LAN}

Pengaturan hukum pidana terhadap anak penyandang disabilitas dapat dilihat melalui berbagai instrumen hukum yang terdiri dari, Ratifikasi Konvensi mengenai Hak-Hak Penyandang Disabilitas (Convention on the Rights of Persons with Disabilities) melalui Undang-Undang Nomor 19 Tahun 2011, Undang-Undang Nomor 8 Tahun 2016 tentang Penyandang Disabilitas, Undang-Undang Nomor 11 Tahun 2012 tentang Sistem Peradilan Pidana Anak, dan Peraturan Daerah Provinsi Daerah Istimewa Yogyakarta Nomor 4 Tahun 2012 tentang Perlindungan dan Pemenuhan Hak-Hak Penyandang Disabilitas.

Konsep pelaksanaan diversi terhadap anak penyandang disabilitas sebagai pelaku tindak pidana dapat dilaksanakan di setiap sistem proses peradilan pidana anak yang mana wajib mengupayakan diversi disetiap tahapannya. Namun pola pelaksanaan diversi melalui kajian putusan hakim belum dapat ditemukan kasus spesifik anak penyandang disabilitas sebagai pelaku, namun secara umum diversi sudah dilaksanakan sesuai dengan persyaratan dapat dilakukannya diversi, meskipun hanya Pengadilan Negeri Wonosari yang memiliki sarana yang cukup bagi anak sebagai penyandang disabilitas. 


\section{B. SARAN}

Akses keadilan dalam penyelesaian tindak pidana yang dilakukan oleh anak sebagai penyandang disabilitas harus lebih diperhatikan. Terutama terkait dengan kemampuan aparat penegak hukumnya dalam menerapkan diversi bagi anak penyandang disabilitas, maupun fasilitas pada setiap tahapan dalam peradilan pidana anak. Selain itu ketentuan terhadap rumah tahanan harus memperhatikan keperluan anak penyandang disabilitas dengan menyediakan Unit Layanan Disabilitas sebagaimana ketentuan dalam undangundang.

\section{DAFTAR PUSTAKA}

\section{Buku}

A dussalam. (2007). H ukum Perlindungan A nak. Jakarta: Restu Agung.

Colbran, Nicola. (2010). A kses Terhadap K eadilan Penyandang D isabilitas Indonesia. Laporan Kajian.

Eko, Riyadi. all (2012). Vulnarable Groups: Kajian dan M ekanisme Perlindungannya. Yogyakarta: PU SH AM UII.

Djamil, M. Nasir (2013). A nak Bukan U ntuk di H ukum. Jakarta: Sinar Grafika.

Eddyono, Supriyadi. Widodo., \& Kamilah, Ajeng. Gandini. (2015). A spek Criminal Justice bagi Penyandang $D$ isabilitas. Jakarta: Institute for C riminal Justice Reform.

H adisuprapto, Paulus. (1997). Juvenile D eliquency Pemahaman dan Penanggulangannya. Bandung: A ditya Bakti.

H enrt A rianto, (2016) H ak-H ak Para Penyandang Cacat (Disabilitas) dalam M emperoleh K eadilan, U niversitas Esa Unggul- 2016/2017

Kartono, Kartini. (2011). Patologi Sosial 2: K enakalan Remaja. Jakarta: Raja Grafindo Persada.

Lalapraing, Yakobus. N. (2016). Pemberdayaan Bagi Penyandang D isabilitas. Sumba Barat: Yayasan Bahtera Tana Rana dan Bali Ledo.

Listyoning, Deby. (2016). H ubungan Pengetahuan 0 rang Tua dalam Pemilihan Jajanan dengan 0 besitasPada A nak Disabilitas di SL B N egeri 1 Bantul. N askah Publikasi.

M, Syafi'e. (2014). Potret Disabel berhadapan dengan H ukum N egara. Yogyakarta: Sigab.

M arlina. (2008). Penerapan K onsep D iversi Terhadap A nak
Pelaku Tindak Pidana dalam Sistem Peradilan Pidana A nak. Jurnal Equity, Vol 1.

Mulyana, Debby. (2009). Komunikasi Antar Budaya (Panduan Berkomunikasi dengan 0 rang-0 rang Berbeda Budaya. Bandung: Remaja Rosdakarya.

Pawening, Medinar. R. (2013). U paya Peningkatan K esejahteraan Sosial Penyandang Cacat M elalui Rehabilitas Sosial (Studi pada U nit Pelaksana Teknis Rehabilitasi Sosial C acat Tubuh di Pasuruan Dinas Sosial Pemerintah Provinsi Jawa Timur. Surabaya: Skripsi UPN Jawa timur.

Pramukti, Angger. Sigit., \& Fuady Primaharsya. (2015). Sistem Peradilan Pidana Anak. Jakarta: Pustaka Yustisia.

Reksodiputro, M ardjono. (1994). K riminologi dan Sistem Pengadilan Pidana Kumpulan Karangan Buku K edua. Jakarta: Pusat Pelayanan Keadilan dan Pengabdian H ukum U niversitas Indonesia.

Siregar, Mahmul., \& DKK. (2007). Pedoman Praktis $M$ elindungi A nak dengan H ukum Pada Situasi E mergency dan Bencana Alam. Medan: Pusat Studi Kajian dan Perlindungan Anak (PKPA).

Supeno, Hadi. (2010). K riminalisasi Anak Tawaran Gagasan Radikal Peradilan Anak Tanpa Pemidanaan. Jakarta: G ramedia Pustaka U tama.

Thohari, Slamet. (2014). Pandangan Disabilitas dan A ksibilitas Fasilitas Publik Bagi Penyandang Disabilitas Kota M alang. Indonesia Journal of D isabiliy Studies ISSN : 2355-2158 Vol 1. I sSue 1.

Wahyudi, Setya. (2010). Implementasi I de D iversi: D alam Pembaruan Sistem Peradilan Pidana A nak di Indonesia. Yogyakarta: Genta Publishing.

\section{Jurnal}

A riani, N evey Varida, 2014, I mplementasi U ndang-U ndang N omor 11 Tahun 2012 Tentang Sistem Peradilan Pidana A nak Dalam U paya M elindungi K epentingan Anak, Jurnal Media Hukum, Vol. 21 No. 1.

\section{U ndang-U ndang}

Kitab Undang-U ndang Hukum Perdata

U ndang-U ndang Nomor 8 Tahun 2016 tentang Penyandang Disabilitas, yang dimaksud penyandang disabilitas 
U ndang-U ndang N omor 11 Tahun 2012 tentang Sistem Peradilan Pidana Anak

Internet

Disabilitas dan Pandangan Masyarakat, http:/ / teknohere.com/ disabilitas-dan-pandangan-masyarakat/ . diunduh pada tanggal 30 November 2016, Pukul. 20.02 WIB.

DS. D ewi.Restoratif Justice, D iversionary Schemes and Spe cial Children's courts In Indonesia. www.kemlu.go.id/ canberra/ List/ Lembarinformasi/ A ttachments/ 61/ RestoratifJustice, diunduh pada tanggal 30 November 2016, Pukul. 20.02 WIB. 